\title{
Effects of temperature on the incorporation of leucine and thymidine by bacterioplankton and bacterial isolates
}

\author{
Brian J. Tibbles* \\ Marine Biology Research Institute, Department of Zoology, University of Cape Town, Private Bag, \\ Rondebosch 7700 , South Africa
}

\begin{abstract}
The effect of temperature on the incorporation of ${ }^{3} \mathrm{H}$-leucine $\left({ }^{3} \mathrm{H}\right.$-Leu) and ${ }^{3} \mathrm{H}$-thymidine ( $\left.{ }^{3} \mathrm{H}-\mathrm{TdR}\right)$ by bacterioplankton and bacterial isolates from marine, estuarine, and freshwater habitats was examned. There was a significant, positive correlation between in situ temperature and molar Leu:TdR incorporation by bacterioplankton in oceanic and lagoonal environments. Temperature manipulation experiments showed that $Q_{11}$ values for Leu incorporation by bacterial assemblages and isolates were significantly higher than corresponding $Q_{10}$ values for $T d R$ incorporation. Evidence indicated that the temperature-dependence of Leu:TdR ratios was not a function of community composition, unbalanced growth, non-specific labelling of macromolecules, or substrate limitation. Thus, Leu and TdR incorporation appear to be affected by temperature differently. These experiments indicate that Leu and/or TdR conversion factors, for estimating bacterial production, are not constant with respect to temperature.
\end{abstract}

KEY WORDS: Temperature $\cdot$ Leucine $\cdot$ Thymidine $\cdot$ Bacterial production

\section{INTRODUCTION}

Measurements of bacterial biomass and production over the past 15 yr have established the importance of heterotrophic bacteria in the trophic dynamics of marine and limnic ecosystems (Azam et al. 1983, Cho \& Azam 1988, Cole et al. 1988, Fuhrman et al. 1989, Ducklow \& Carlson 1992, Simon et al. 1992). This realisation has stimulated considerable interest in the measurement of organic matter and energy flux through bacterial communities in attempts to elucidate the fundamental biogeochemical cycles and foodweb structures of various aquatic ecosystems.

Studies of heterotrophic bacterial production are limited by the reliability of the techniques used to measure this process. The methodology of the various techniques available for this purpose has therefore been a focus of attention. Despite the criticism and controversy of its methodological shortcomings (see Robarts

-Address for correspondence: PO Box 1566, Florida 1710, South Africa. E-mail: btibbles@botzoo.uct.ac.za
\& Zohary 1993 for review), the measurement of tritiated thymidine incorporation (TTI) into cold trichloroacetic acid (TCA)-insoluble material (Fuhrman \& Azam 1982, Moriarty 1986) has been used more frequently to date than any other method (Ducklow \& Carlson 1992). More recently, the measurement of radiolabelled leucine incorporation (LI) into bacterial protein (Kirchman et al. 1985, Simon \& Azam 1989) has also found favour. The use of LI and TTI for comparative purposes in the same study is considered a worthwhile approach to assess the reliability of the data (Chin-Leo \& Kirchman 1988, 1990, Servais 1992, Simon 1994).

Both TTI and LI require conversion factors to estimate biomass production from measured rates of substrate uptake. These factors may be derived from either a theoretical or an empirical basis. The accuracy of conversion factors for calculating production from TTI has been a subject of considerable debate (Moriarty 1988, Bell 1990. Ducklow \& Carlson 1992, Robarts \& Zohary 1993). Notwithstanding these considerations, it has been argued that bacterial production estimated by TTI should approximate that estimated by LI for a 
given bacterial assemblage under conditions of balanced growth (Chin-Leo \& Kirchman 1990, Servais 1992). This argument rests on the assumption that conversion factors for TTI and LI are constant for the same assemblage growing under different environmental conditions (e.g. temperature). Although TTI and LI are often reported to yield approximately equivalent estimates of bacterial production (Chin-Leo \& Kirchman 1988, Kirchman \& Hoch 1988, Riemann \& Bell 1990, Bjornsen \& Kuparinen 1991, Servais 1992), conditions of unbalanced growth could give rise to discrepancies in these estimates. Chin-Leo \& Kirchman (1990) have reported that the carbon:DNA ratio of bacteria varied 2 -fold depending on the growth state, and that the delay between unbalanced growth and shifts in the growlh rate was shorter than tho goneration time. The possibility that temperature may further contribute to discrepancies between TTI and LI has not been examined to date.

Leucine and thymidine are incorporated into protein and DNA, respectively, by different biochemical pathways. Temperature is an environmental variable that is well known to influence enzyme kinetics. The present study examines the effect of temperature on LI in comparison to its effect on TTI, by heterotrophic bacterioplankton from different aquatic habitats.

\section{MATERIALS AND METHODS}

The effect of temperature on the incorporation of $\mathrm{TdR}$ and Leu was examined in natural assemblages and in selected bacterial isolates. Experiments with natural assemblages were carried out at in situ temperatures and at laboratory-controlled temperatures as follows.

Effect of in situ temperature on Leu and TdR incorporation by bacterioplankton assemblages. Study sites: The Subtropical Convergence (STC) to the south of Africa is a prominent surface thermal front, exhibiting a strong temperature gradient where Subantarctic and Subtropical Surface Waters meet (Lutjeharms \& Valentine 1984). A cruise of the South African Antarctic Marine Ecosystems Study to this region $\left(40^{\circ} 00^{\prime}\right.$ to $43^{\circ} 30^{\prime} \mathrm{S} .19^{\circ} 00^{\prime}$ to $22^{\circ} 30^{\prime} \mathrm{E}$ ) in June-July 1993 aimed to improve our understanding of processes controlling carbon flux at the STC during winter. One component of these studies was the role of heterotrophic bacterial processes in carbon flux relative to primary production and bacterivory. Our survey of the STC included three 36 h stations: one to the north of, one in the middle of, and one to the south of the convergence. In addition, several other stations were located at positions within or near to a warm water eddy to the south of the convergence. At the STC stations, water samples for bac- terial abundance and production measurements were taken twice daily from 5 or 6 different depths; one sample was taken in the morning (at ca 09:00 h), and the other in the evening (at ca 17:00 h). At the eddy stations, water samples were taken once a day (during the morning), and from only 2 depths (from the surface and from the subsurface chlorophyll maximum). Samples were collected by 81 Niskin bottles on a CTD rosette (General Oceanics, Mark III) and processed onboard (see below).

The effects of in situ temperatures on LI and TTI were also examined at Langebaan Lagoon, a saltmarsh ecosystem situated at $33^{\circ} 00^{\prime}$ to $30^{\circ} 13^{\prime} \mathrm{S}, 17^{\circ} 57^{\prime}$ to $18^{\circ} 08^{\prime} \mathrm{E}$ on the southwest coast of South Africa. This lagoon is a partially enclosed marine system with no riverine input. so that salinity values are relatively constant and approximate those of seawater (Shannon \& Stander 1977). On 29 January 1996 (between 07:30 and $14: 30 \mathrm{~h}$ ), surface water samples (200 ml) were collected in sterile glass bottles around the shore of the lagoon for analysis of Leu and TdR incorporation and bacterial abundance

Measurement of Leu and TdR incorporation: Duplicate samples $(20 \mathrm{mI})$ were incubated with $5 \mathrm{nM}$ [methyl- ${ }^{3} \mathrm{H}$ ] thymidine $\left(84 \mathrm{Ci} \mathrm{mmol}^{-1}\right.$; Amersham UK) or $11 \mathrm{nM}$ leucine $\left\{1 \mathrm{nM}\left[3,4,5-{ }^{3} \mathrm{H} \mid \mathrm{L}\right.\right.$-leucine $(140 \mathrm{Ci}$ $\mathrm{mmol}^{-1}$; Amersham, UK) and $10 \mathrm{nM}$ nonradioactive L-leucine at in situ temperatures for $2 \mathrm{~h}$ (oceanic samples) or $15 \mathrm{~min}$ (lagoon samples). Previous studies of TTI by Langebaan Lagoon bacterioplankton during summer indicated that isotope dilution of ${ }^{3} \mathrm{H}-\mathrm{TdR}$ could be inhibited by $5 \mathrm{nM}$ additions of ${ }^{3} \mathrm{H}-\mathrm{TdR}$, and that an incubation period of $15 \mathrm{~min}$ was within the limits where TTI was linear with time (Tibbles et al. 1992). Isotope dilution and linearity of LI by lagoonal bacterioplankton were not examined by Tibbles et al. (1992). Rates of TTI by oceanic bacterioplankton were saturated when additions of $5 \mathrm{nM}$ were used, whereas LI was not saturated when additions of $10 \mathrm{nM}$ were used (see below). Preliminary time-series experiments indicated that an incubation period of $2 \mathrm{~h}$ was within the limits where rates of LI and TTI by oceanic samples were linear with time.

Incubations were terminated by the addition of $1 \%$ formalin. Bacteria were then collected by filtration of samples through $0 . \bar{Z} 2 \mathrm{~m}$ celiuiuse dceiate filiters (Millipore Corp.). Filters were washed twice with $5 \mathrm{ml}$ ice-cold 5\% (w/v) trichloroacetic acid, and twice with $5 \mathrm{ml}$ ice-cold $80 \%(\mathrm{v} / \mathrm{v})$ ethanol. Filters and filter margins were then washed 5 times with $1.5 \mathrm{ml}$ ice-cold $80 \%(\mathrm{v} / \mathrm{v})$ ethanol, and placed into scintillation vials with $5 \mathrm{ml}$ FilterCount (Packard). Disintegrations per minute were determined in a Beckman LS 5000TD scintillation counter, after the filters had dissolved completely in the scintillant. 
Effect of laboratory-controlled temperature on Leu and TdR incorporation by natural assemblages in single samples. Study sites: Habitats that had experienced minimal human impact, and were in close proximity to the laboratory, were selected for study during May to June 1995 (winter) and November 1995 to January 1996 (summer). Seawater samples were collected from Oudekraal on the west coast of the Cape Peninsula $\left(34^{\circ} 00^{\prime} \mathrm{S}, 18^{\circ} 25^{\prime} \mathrm{E}\right)$, South Africa. This site represents inshore, south Atlantic central water (ca $12^{\circ} \mathrm{C}$ ) and lies within the cool Benguela upwelling system. Freshwater samples were taken from a pristine mountain stream (ca $13^{\circ} \mathrm{C}$ in winter and ca $16^{\circ} \mathrm{C}$ in summer) in Skeleton Gorge on Table Mountain, Cape Peninsula, while estuarine water was collected from the Rooi-Els estuary (ca $12^{\circ} \mathrm{C}$ ) situated along the Cape south coast. Both Skeleton Gorge and Rooi-Els occur within the Cape fynbos biome, which is characterized by high-level plant species diversity and low nutrient concentrations. Samples were transported within 45 min to the laboratory in an insulated container.

Incorporation assays: Each sample $(1000 \mathrm{ml})$ was mixed by inverting the bottle several times to ensure homogenous distribution of bacteria, and subdivided into 3 equal subsamples. Each subsample was acclimated to an incubation temperature [viz. $3^{\circ} \mathrm{C}, 12$ to $15^{\circ} \mathrm{C}$ (approximating the in situ temperature for these habitats), or $30^{\circ} \mathrm{C}$ ] for 1 to $8 \mathrm{~h}$. Subsamples were then aliquoted (10 to $20 \mathrm{ml}$ ) into polyethylene vials in duplicate for each substrate. Rates of Leu and TdR incorporation were measured according to the protocol above, except that incubations were terminated after 30 or $60 \mathrm{~min}$. For inshore seawater samples from Oudekraal, preliminary time-series experiments indicated that 30 to 60 min was within the limits where rates of LI and TTI were linear with time. Rates of TTI by inshore bacterioplankton were saturated when additions of $5 \mathrm{nM}$ were used, whereas LI was not saturated when additions of $10 \mathrm{nM}$ were used (see below). Substrate saturation and linearity of LI and TTI were not examined for the estuarine and limnic samples.

Enzymatic hydrolysis. Seawater samples from Oudekraal were acclimated to temperatures of 4,12 , and $30^{\circ} \mathrm{C}$ for 6 to $8 \mathrm{~h}$. Subsamples $(40 \mathrm{ml})$ were thereafter incubated with $5 \mathrm{nM}$ [methyl- $\left.{ }^{3} \mathrm{H}\right]$ thymidine (83 $\mathrm{Ci}$ $\mathrm{mmol}^{-1}$ ) or $10 \mathrm{nM}^{3} \mathrm{H}$-Leu $\left(17 \mathrm{Ci} \mathrm{mmol}^{-1}\right)$, unless otherwise stated, for $1 \mathrm{~h}$. Substrate uptake was terminated by placing samples on ice and adding $5 \mathrm{ml}$ ice-cold $100 \%(\mathrm{w} / \mathrm{v})$ TCA. Macromolecules were collected on $0.45 \mathrm{~m}$ cellulose acetate filters (Millipore Corp., $25 \mathrm{~mm}$ diameter) after precipitation at $0^{\circ} \mathrm{C}$ for $1 \mathrm{~h}$. Filters were washed twice with $5 \mathrm{ml}$ ice-cold $5 \%$ TCA, and thrice with $5 \mathrm{ml}$ ice-cold $80 \%$ ethanol. Filters and filter margins were then washed 5 times with $1.5 \mathrm{ml}$ ice-cold $80 \%$ ethanol, before excess TCA was neu- tralised with $3 \mathrm{ml}$ ice-cold $10 \mathrm{mM} \mathrm{NaHCO}_{3}$. Filters were dried and then stored overnight at $-20^{\circ} \mathrm{C}$ before enzymatic hydrolysis of macromolecules was carried out, essentially according to the methods of Robarts et al. (1986) and Torréton \& Bouvy (1991).

DNase I (Seravac, $3715 \mathrm{U} \mathrm{mg}^{-1}$ ) digestions of duplicate samples were carried out in $20 \mathrm{mM}$ morpholinepropanesulfonic acid (MOPS), $0.5 \mathrm{mM} \mathrm{CaCl}_{2}$ (pH 7.5); RNase A (Sigma, 85 Kunitz $\mathrm{U} \mathrm{mg}^{-1}$ ) digestions were carried out in $20 \mathrm{mM}$ MOPS ( $\mathrm{pH} 7.5$ ); and proteinase $\mathrm{K}$ (Merck, $30 \mathrm{~m}$ Anson $\mathrm{U} \mathrm{mg}^{-1}$ ) digestions were carried out in $20 \mathrm{mM}$ Tris buffer $(\mathrm{pH} \mathrm{8.0)}$. Specificity of the digestions was ensured as follows: DNase digestions were carried out in the presence of $1 \mu$ placental RNase

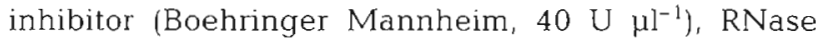
stock solutions were heated at $100^{\circ} \mathrm{C}$ for $10 \mathrm{~min}$ to remove contaminating DNase (Sambrook et al. 1989), and proteinase $\mathrm{K}$ was purchased as nuclease-free.

Enzymatic digestions of macromolecules on filters were performed by adding $2.5 \mathrm{ml}$ of the appropriate buffer to the vials containing the filters with appropriate enzymes at final concentrations of 10 and $50 \mu \mathrm{g}$ $\mathrm{ml}^{-1}$; results at both concentrations were similar, indicating that the concentrations of enzymes were not a limiting factor of completion of the digestions. In addition to enzymatic digestions, control samples without enzyme additions were included in duplicate. All samples were incubated at $37^{\circ} \mathrm{C}$ on a shaker for $2 \mathrm{~h}$, whereafter the filters were separated from the bufferenzyme solutions. Filters were dissolved in $1 \mathrm{ml}$ ethylacetate before addition of $4 \mathrm{ml}$ UltimaGold XR scintillation fluid (Packard). Scintillation fluid $(10 \mathrm{ml})$ was also added to the vials containing the buffer-enzyme solutions. Disintegrations per minute were determined in solution and remaining on the filters using a scintillation counter

Leu and $\mathrm{TdR}$ incorporation by isolates. The effects of temperature on LI and TTI by heterotrophic bacterial isolates from freshwater and marine habitats were also examined. Isolations were made, and strains were maintained, at $15^{\circ} \mathrm{C}$ on tryptone agar $\left(5 \mathrm{~g} \mathrm{l}^{-1}\right.$ tryptone, $12 \mathrm{~g} \mathrm{l}^{-1}$ agar) or marine agar (Difco). Standard biochemical tests, described in detail by Smibert \& Krieg (1981), were used for biochemical and physiological characterization of the isolates. Four strains which could grow in minimal media were examined, including 1 strain from the Southern Ocean (strain SO55, isolated at approximately $42^{\circ} \mathrm{S}, 14^{\circ} \mathrm{E}$ during JanuaryFebruary 1993), 1 strain from Oudekraal (strain O2), and 2 strains from Skeleton Gorge (strains SG5 and SGG).

Isolated colonies of the freshwater strains were inoculated into $100 \mathrm{ml}$ minimal medium M9 $(42 \mathrm{mM}$ $\mathrm{Na}_{2} \mathrm{HPO}_{4}, 25 \mathrm{mM} \mathrm{NaH} \mathrm{PO}_{4}, 9 \mathrm{mM} \mathrm{NaCl}, 20 \mathrm{mM}$ $\mathrm{NH}_{4} \mathrm{Cl}, 2 \mathrm{mM} \mathrm{MgSO}_{4}$ and $1 \mathrm{mM}$ glucose), whereas the 
marine strains were inoculated into marine $\mathrm{M} 9$ (which was $\mathrm{M} 9$ containing $30 \mathrm{~g} \mathrm{l}^{-1} \mathrm{NaCl}$. Cultures were incubated at $15^{\circ} \mathrm{C}$ for $24 \mathrm{~h}$ before they were used to subinoculate $100 \mathrm{ml}$ volumes of appropriate media equilibrated to either 4,15 , or $30^{\circ} \mathrm{C}$. After incubation at these temperatures for $24 \mathrm{~h}$, these cultures were used to make a second subculture, which was incubated until cell densities reached ca $10^{8}$ cells ${ }^{-1}$. Subsamples $(10 \mathrm{ml})$ were then incubated with $10 \mathrm{nM}$ [methyl${ }^{3} \mathrm{H}$ )thymidine $\left(83 \mathrm{Ci} \mathrm{mmol}^{-1}\right.$ ) or $20 \mathrm{nM}{ }^{3} \mathrm{H}$-leucine $\left(17 \mathrm{Ci} \mathrm{mmol}^{-1}\right.$ ) for $15 \mathrm{~min}$. Time-course studies showed that LI and TTI by these cultures were linear for at least $30 \mathrm{~min}$. Substrate saturation was not examined during these culture studies. Substrate incorporation was terminated, and samples were processed further as described above.
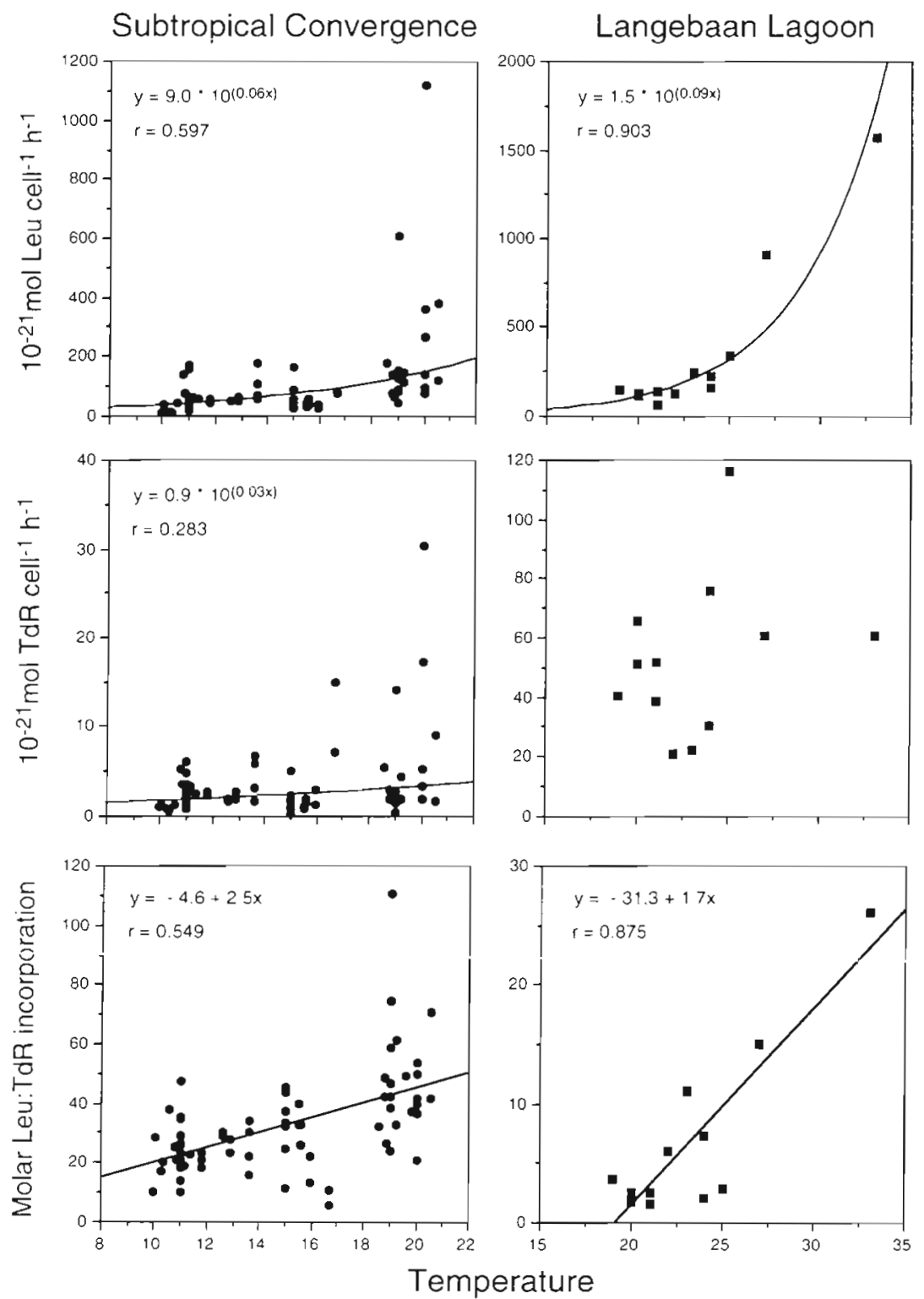

Bacterial abundance. Bacterial abundance was measured by epifluorescence microscopy using the method of Porter \& Feig (1980).

\section{RESULTS}

Effect of in situ temperature on Leu and TdR incorporation by natural bacterial assemblages

Cell-specific rates of LI and TTI by oceanic bacteria at the Subtropical Convergence were positively correlated with temperature (Fig. 1). Rates of LI by lagoonal bacterioplankton were also positively correlated with temperature, but no relationship was evident between TTI by lagoonal bacteria and temperature (Fig. 1). These comparisons suggest that LI and TTI by natural assemblages rospond to temperature differently. For both oceanic and lagoonal samples, molar ratios of Leu:TdR incorporation were positively, and significantly $(p<0.001)$, correlated with temperature (Fig. 1).

\section{Effect of laboratory-controlled temperature on TdR and Leu incorporation by bacterial assemblages in single samples}

To minimize the influence that bacterial community composition might have on ratios of Leu:TdR incorporation, subsamples of single samples were assayed for substrate incorporation at different, laboratorycontrolled temperatures. Two seawater samples were collected ca $10 \mathrm{~m}$ apart from the rocky shore at Oudekraal, and acclimated for $2 \mathrm{~h}$ to the incubation temperatures prior to the assays. Although cell-specific TTI rates were similar for the 2 samples, cell-specific LI was approximately 10 -fold higher tor sample 2 than for

Fig. 1 Effect of temperature on cell-specific rates of LI (leucine incorporation) and TTI (tritiated thymidine incorporation) and on the molar ratio of Leu:TdR incorporation by oceanic and lagoonal bacterioplankton at the Subtropical Convergence $(\bullet)$ and Langebaan Lagoon ( respectively 
sample 1 (Fig. 2). Consequently, Leu:TdR incorporation ratios were approximately 10 -fold higher for sample 2 than for sample 1 , indicating that assemblages in different samples from the same site can differ in $\mathrm{LI}$ and TTI characteristics. The temperature response of LI and TTI by Oudekraal samples was psychrotrophic-mesophilic, with a temperature optimum for both substrates at about $25^{\circ} \mathrm{C}$. Despite the relatively lower rates of $\mathrm{LI}$ and TTI at temperatures $>25^{\circ} \mathrm{C}$. molar ratios of Leu:TdR incorporation increased with temperature over the whole temperature range (Fig. 2).

To compare the responses (in terms of LI and TTI) of marine, estuarine, and limnic plankton to temperature, water samples were collected from Oudekraal, Rooi-Els, and Skeleton Gorge, respectively. Although in situ temperatures for these 3 habitats were similar (ca 12 to $16^{\circ} \mathrm{C}$ ), the temperature response of LI and TTI by Oudekraal samples was different to the responses by Rooi-Els and Skeleton Gorge samples. Substrate uptake by Oudekraal seawater (Fig. 3) reflected the psychrotrophic-mesophilic response described in Fig. 2, uptake rates in Oudekraal samples were lower at $30^{\circ} \mathrm{C}$ than at $12^{\circ} \mathrm{C}$ (Fig. 3). In contrast, uptake rates by Rooi-Els estuarine and Skeleton Gorge freshwater stream samples increased with temperature, and were higher at $30^{\circ} \mathrm{C}$ than at $12^{\circ} \mathrm{C}$. Molar ratios of Leu:TdR incorporation increased with temperature for all 3 habitats (Fig. 3) although ratios were higher for stream samples than for estuarine and seawater samples; this pattern reflects the pattern obtained for Oudekraal previously (Fig. 2).

The incorporation of tritium from ${ }^{3} \mathrm{H}-\mathrm{TdR}$ and ${ }^{3} \mathrm{H}$-Leu into different biochemical fractions of plankton assemblages was examined. Enzymatic hydrolysis of ${ }^{3} \mathrm{H}$-Leu and ${ }^{3} \mathrm{H}$-TdR labelled, cold-TCA precipitate from Oudekraal seawater was carried out during 2 experiments (Fig. 4). Rates of incorporation of ${ }^{3} \mathrm{H}$-Leu and ${ }^{3} \mathrm{H}$-TdR were higher during the second experiment than during the first, whereas Leu:TdR incorporation ratios were higher during the first experiment than during the second. Molar ratios of Leu:TdR incorporation increased with temperature for both experiments. Regardless of incubation temperature, most of the radiolabel from ${ }^{3} \mathrm{H}$-Leu $(73$ to $100 \%$ ) and ${ }^{3} \mathrm{H}-\mathrm{TdR}$ (87 to $97 \%$ ) was incorporated into the protein and DNA fractions, respectively. Consequently, enzymatic hydrolysis provided no evidence that temperature-dependent Leu:TdR ratios were a function of variation in macromolecule radiolabelling patterns.

The effect of substrate concentration on rates of LI and TTI by oceanic and inshore bacterioplankton was examined. Rates of TTI by oceanic and inshore bacterioplankton were saturated when additions of
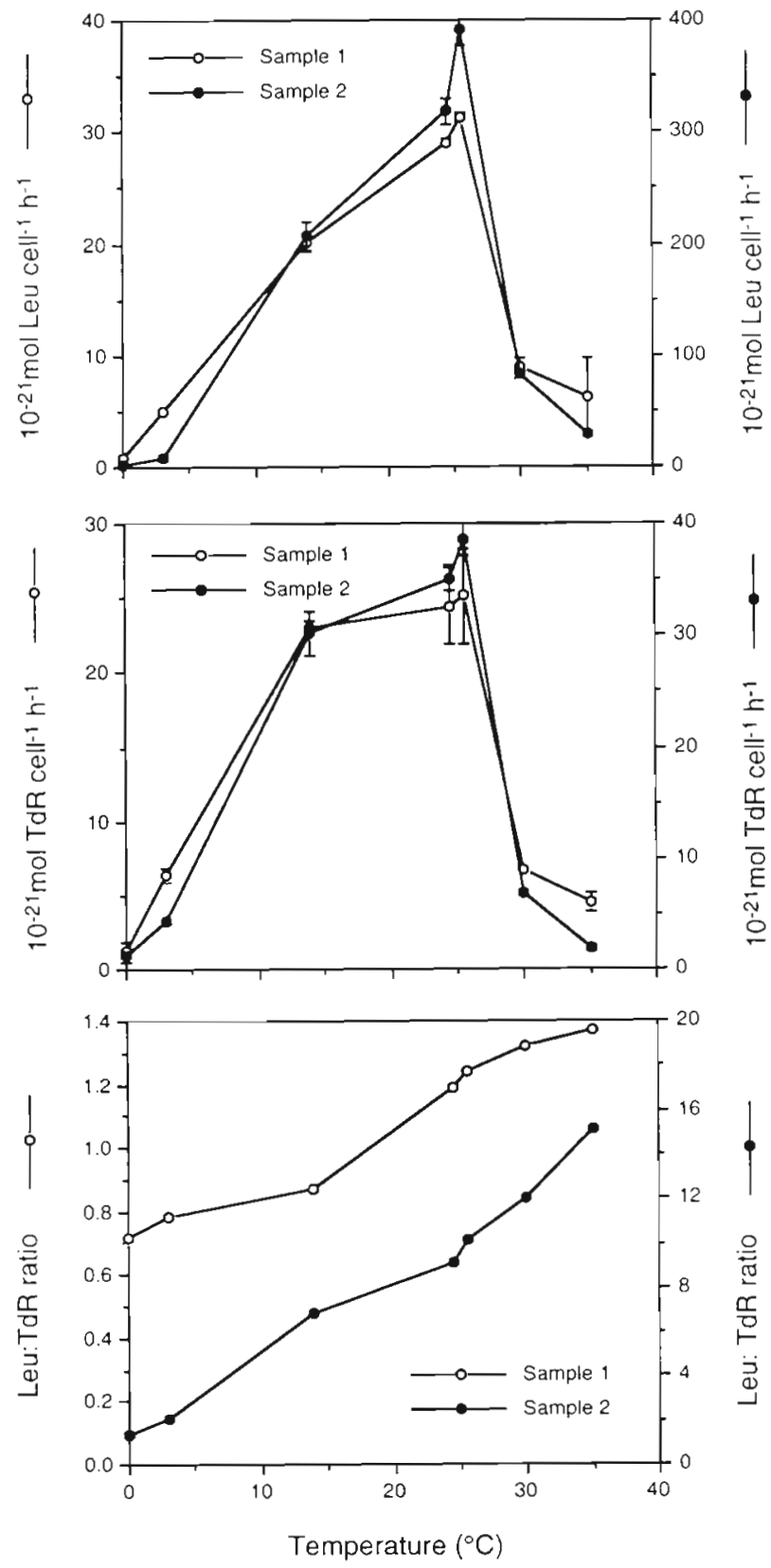

Fig. 2. Effect of temperature on LI, TTI, and the molar ratio of Leu:TdR incorporation by 2 seawater samples from Oudekraal. Values for LI and TTI represent means \pm SD for duplicate measurements, whereas Leu:TdR ratios were calculated from mean values only

$5 \mathrm{nM}$ were used, whereas LI was not saturated when additions of $10 \mathrm{nM}$ were used (Fig. 5). Moreover, molar Leu:TdR incorporation by inshore bacterioplankton also increased with temperature at higher substrate concentrations ([TdR] at 5, 10, $30 \mathrm{nM}$, [Leu] at 10, 20,60 nM; Fig. 6), indicating that temperaturedependent Leu:TdR incorporation was not a function of substrate limitation. 


\section{Leu and $\mathrm{T} d \mathrm{R}$ incorporation by isolates}

Cell-specific rates of TTI by the 2 marine strains were similar, while rates of LI were higher in the Vibrio strain $\mathrm{O} 2$ than in Alcaligenes strain SO55 (Fig. 7). A similar comparison is evident between the 2 freshwater strains (Fig. 8); rates of TTI were similar, whereas rates of LI were higher for Aeromonas strain SGG than for Aeromonas strain SG5. Rates of TTI generally reflected rates of cell yield; rates of TTI were generally higher at $12^{\circ} \mathrm{C}$ than at 3 or $30^{\circ} \mathrm{C}$ (Figs. $7 \& 8$ ), and rates of cell production by all 4 strains were greater at $12^{\circ} \mathrm{C}$ than at 3 or $30^{\circ} \mathrm{C}$ (data not shown). Rates of LI generally increased with temperature (Figs. $7 \& 8$ ). The data in Figs. $7 \& 8$ represent means \pm SD of duplicate experiments. For each isolate, both experiments were performed under similar conditions, except that cultures were grown in different batches of media. Therefore, possible sources of variation include the quality of the media. Although some differences between treatments are statistically insignificant, the trends in the Leu:TdR data indicate that Leu:TdR ratios increased with temperature (Figs. $7 \& 8$ ). This trond for the culture studies reflects those observed for natural assemblages.

\section{DISCUSSION}

Recent cruises to the Southern Ocean established that molar ratios of Leu:TdR incorporation into coldTCA insoluble material were positively correlated with temperature. This pattern was most conspicuous during a ca 40 nautical mile transect of the Subtropical Convergence, a prominent surface thermal front exhibiting a strong thermal gradient. Molar ratios of Leu:TdR incorporation ranged from $26( \pm 10 \mathrm{SD})$ in Subantarctic Surface Water (ca $10^{\circ} \mathrm{C}$ ) just south of the STC to $47( \pm 19$ SD) in Subtropical Surface Water (ca
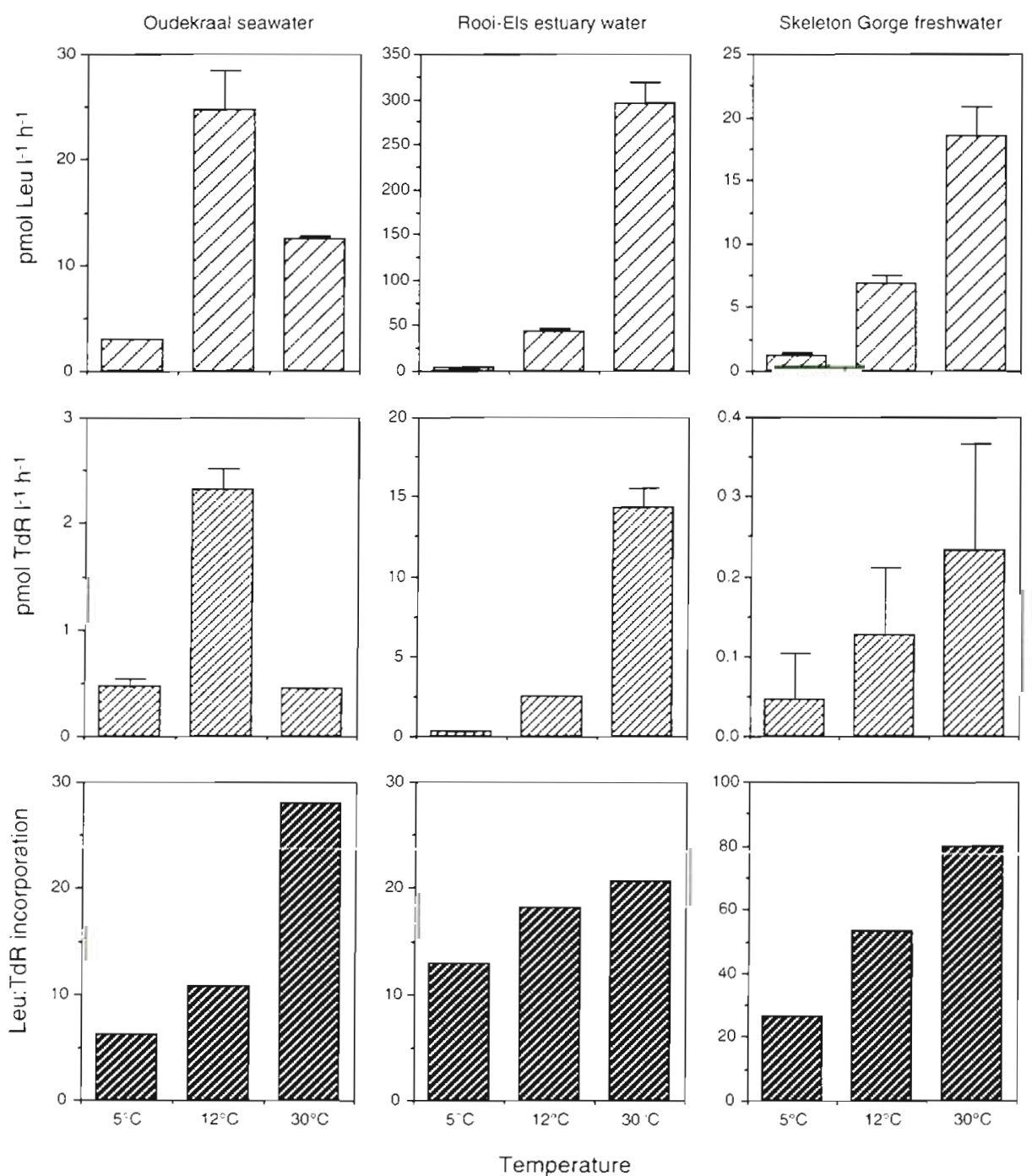

Fig. 3. Effect of temperature on Li, ITI, and the molar ratio of Leu:TdR incorporation by manne bacteria from Oudekraal, estuarine bacteria from Rooi-Els, and freshwater bacteria from Skeleton Gorge. Note that scales for substrate incorporation differ between habitats. Values for LI and TTI represent means $\pm \mathrm{SD}$ for duplicate measurements, whereas Leu:TdR ratios were calculated from mean values only 
$20^{\circ} \mathrm{C}$ ) to the north of the STC (Fig. 1). The relationship between temperature and molar ratios of Leu:TdR incorporation at the STC was found to be statistically significant by regression analysis (Fig 1). Moreover, during a transect of the Southern Ocean from Antarctica to South Africa, Leu-based estimates of bacterial production were ca 8-fold higher than TdR-based estimates in Agulhas Current Water (ca $24^{\circ} \mathrm{C}$ ), whereas estimates from these 2 methods were similar in Antarctic Shelf Water (ca $-1.8^{\circ} \mathrm{C}$; Tibbles unpubl. data).

Studies of LI and TTI by saltmarsh lagoon bacterioplankton supported the trend observed in the Southern Ocean. Molar ratios of Leu:TdR incorporation by lagoon bacteria were also positively correlated with in situ temperature (Fig. 1). These findings suggest that Leu and/or TdR conversion factors for estimating bacterial production are not constant with respect to temperature. However, one problem with the multiple sample approach of these in situ studies is the uncertainty that different bacterial community compositions may incorporate Leu and TdR to different extents (Kirchman et al. 1985, Davis 1989). For example, the Subantarctic Front to the south of the STC is considered to be a biogeographical boundary for microphytoplankton assemblages in the Southern Ocean (Froneman et al. 1995). Since waters of different origin meet at the STC, it is also reasonable to consider that bacterioplankton communities in cold Subantarctic Surface Water to the south of the STC might be physiologically different to those in warm Subtropical Surface Water to the north, adjacent to the Agulhas Current.

To minimise the influence of community composition on Leu:TdR incorporation ratios, the temperature response of LI and TTI by subsamples of single samples was examined. Three different aquatic ecosystems (viz. seawater, estuarine, and freshwater habitats) were included to assess the consistency of trends among ecosystems. Although in situ temperatures for all 3 habitats were similar (ca 12 to $15^{\circ} \mathrm{C}$ ), the temperature response of substrate uptake by seawater samples from Oudekraal was different to that by the estuarine and freshwater habitats. Seawater from Oudekraal showed a psychrotrophic-mesophilic response in uptake rates, with a temperature optimum of about $25^{\circ} \mathrm{C}$ (Fig. 2). Thus, uptake rates in inshore seawater samples were lower
16 November 1995
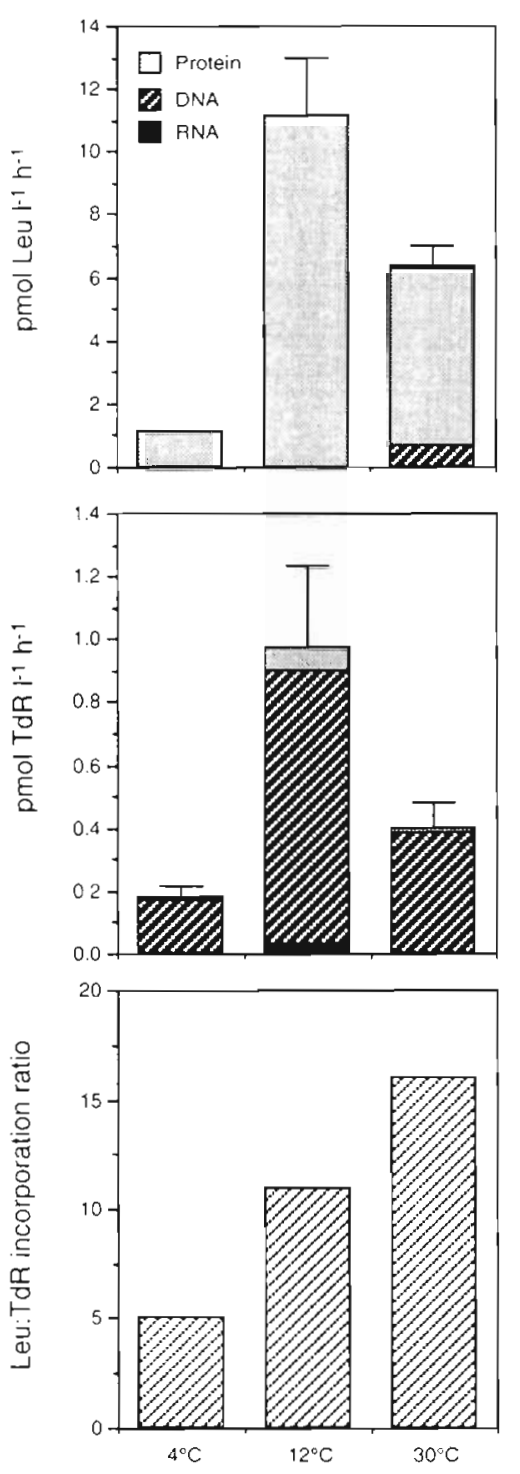

21 November 1995
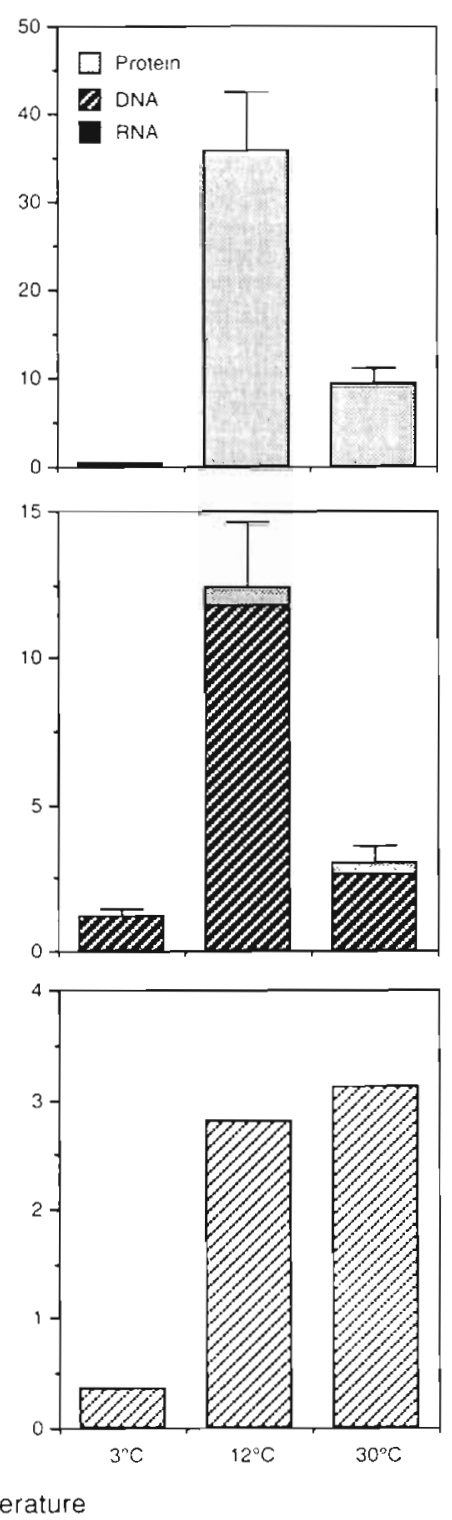

Fig. 4. Incorporation of tritium from ${ }^{3} \mathrm{H}$-Leu and ${ }^{3} \mathrm{H}-\mathrm{TdR}$ into protein, DNA, and RNA by seawater bacteria from Oudekraal. Biochemical fractions were separated by enzymatic digestion with proteinase $\mathrm{K}$, DNase I, and RNase $A$ at $10 \mu \mathrm{g} \mathrm{m} \mathrm{ml}^{-1}$ (16 November 1995) and $50 \mu \mathrm{g} \mathrm{ml} \mathrm{m}^{-1}$ (21 November 1995). Note that scales for substrate incorporation differ between experimental dates. Values for LI and TTI represent means \pm SD for duplicate measurements, whereas Leu:TdR ratios were calculated from mean values only

at $30^{\circ} \mathrm{C}$ than at 12 to $15^{\circ} \mathrm{C}$ (Figs. $2,3 \& 4$ ). In contrast, uptake rates by Rooi-Els and Skeleton Gorge samples increased with temperature, and were higher at $30^{\circ} \mathrm{C}$ than at $12^{\circ} \mathrm{C}$ (Fig. 3).

The temperature response of TTI by aquatic bacteria from Rooi-Els and Skeleton Gorge (Fig. 3) reflected TTI by soil bacteria from Table Mountain, which is also part of the fynbos biome (Tibbles \& Harris 1996). The 


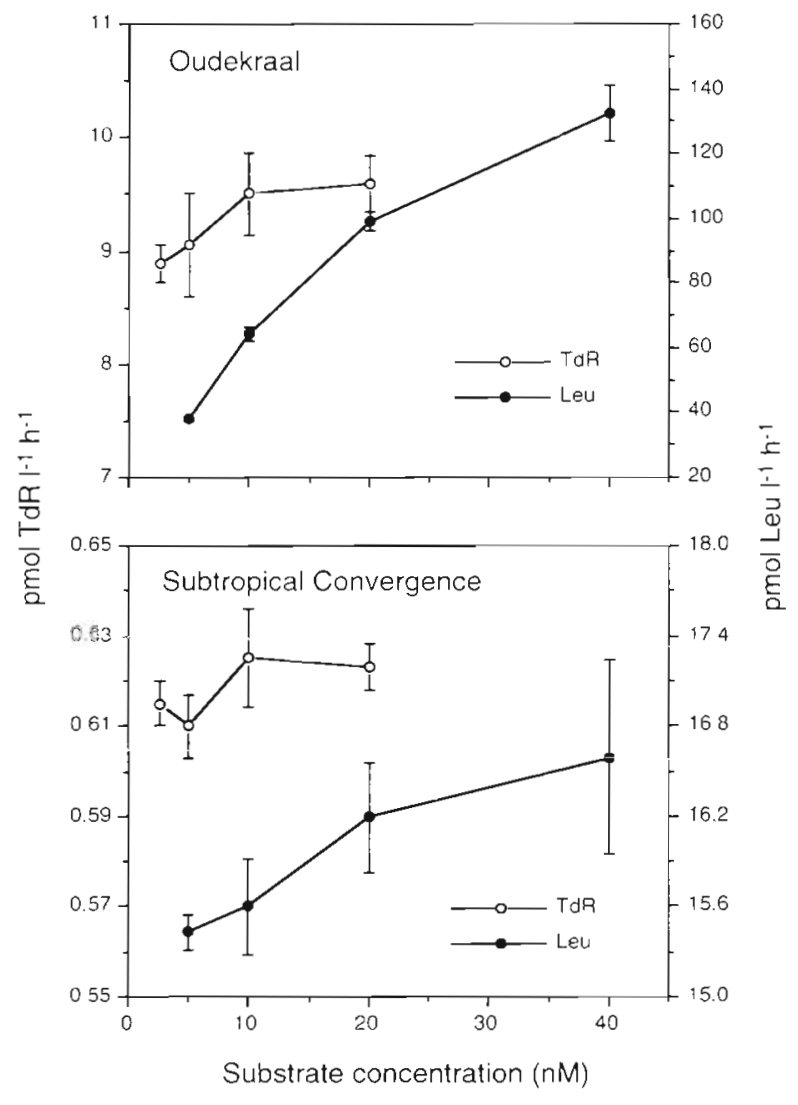

Fig. 5. Effect of substrate concentration on rates of TTI and Ll by inshore (Oudekraal) and oceanic (STC) bacterioplankton

Cape fynbos is a warm temperate biome, where temperatures regularly reach $>30^{\circ} \mathrm{C}$ during summer. In contrast, upwelling of $\mathrm{cool}\left(\mathrm{ca} 10^{\circ} \mathrm{C}\right.$ ) South Atlantic Central Water along the west coast, including Oudekraal, is an important process that regulates the characteristics of the water mass overlying the Benguela continental shelf (Shannon 1985, Lutjeharms \& Valentine 1987). Thus, Rooi-Els and Skeleton Gorge are part of a warmer environment than Oudekraal. Regardless of the temperature response of LI or TTI, Leu: $T d R$ incorporation ratios increased with temperature for all 3 habitats (Fig. 3).

One of the problems of temperature manipulations in single sample studies is the requirement that samples should be acclimated to incubation temperatures to facilitate a state of balanced growth, while they should not change substantially in community composition during acclimation. Changes in community composition could occur by growth, loss (e.g. grazing), or changes in the metabolically active fraction. Samples were acclimated to incubation temperatures for 1 to $8 \mathrm{~h}$, during which time there were no significant changes in bacterial abundance (data not shown); the effect of possible grazing and possible changes in the metabolically active population were not determined. However, the following evidence suggests that temperature-clependent Leu:TdR ratios were not a function of unbalanced growth or community composition: (1) molar Leu:TdR ratios increased with temperature, regardless of the acclimation period ( 1 to $8 \mathrm{~h}$ ); (2) Leu: $\mathrm{TdR}$ incorporation increased with temperature for samples from habitats of diverse aquatic origin, regardless of the growth response to temperature; (3) there was a significant, positive relationship between Leu:TdR ratios and in situ temperature for oceanic and lagoonal bacterioplankton; and (4) culture studies showed that molar Leu:TdR incorporation by isolates was temperature-dependent. Bacteria used in the in situ studies and in culture studies did not experience temperature shift, and are therefore unlikely to have been in unbalanced growth due to this variable. The temperature-dependence of Leu:TdR incorporation by isolates also indicates that community composition was not the cause of temperature-dependent Leu:TdR ratios in plankton studies. Four isolates, including 2 Aeromonas strains from a freshwater stream, a marine Alcaligenes and a Vibrio strain, were examined. All 4 strains showed psychrotrophicmesophilic growth responses to temperature, which were reflected by cell-specific rates of TTI. Cell-specific rates of LI increased with temperature over the temperature range tested $\left(3\right.$ to $\left.30^{\circ} \mathrm{C}\right)$. Consequently, Leu:TdR ratios increased with temperature. These findings clearly demonstrate that TdR and Leu incorporation into cold-TCA precipitate do not respond to temperature in the same way.

The specificity of ${ }^{3} \mathrm{H}$-TdR for DNA has been a topic of considerable debate (Karl 1982, Moriarty 1986, Robarts et al. 1986, Hollibaugh 1988, Robarts \& Wicks

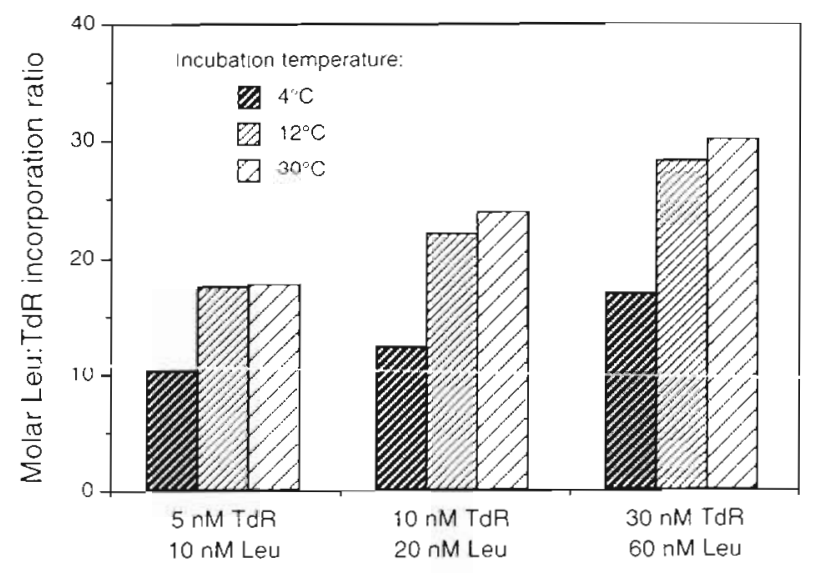

Substrate concentration

Fig. 6. Effects of substrate concentration and temperature on the molar ratio of Leu:TdR incorporation by inshore bacterioplankton 
1989, Kirchman 1992, Robarts \& Zohary 1993), while the specificity of radiolabelled Leu for protein has also been examined (Kirchman et al. 1985, Chin-Leo \& Kirchman 1988). Argument against unbalanced growth and/or community composition as possible causes of temperature-dependent Leu:TdR ratios in. cold-TCA precipitate does not preclude the possibility that variation in Leu:TdR incorporation might be an artifact of temperature-dependent, non-specific labelling of macromolecules. Therefore, cold-TCA insoluble material was fractionated by enzymatic hydrolysis to determine the location of radiolabel from ${ }^{3} \mathrm{H}$-Leu and ${ }^{3} \mathrm{H}-\mathrm{TdR}$ during incorporation at different temperatures. I found that the protocol of Robarts et al. (1986), as modified by Torréton \& Bouvy (1991) and employed in the present study with longer digestion periods, was more effective than the sonication procedure of Servais et al. (1987) for my samples. Enzymatic digestion indicated that 73 to $100 \%$ of radiolabel from ${ }^{3} \mathrm{H}$-Leu was incorporated into protein, while 87 to $97 \%$ of radiolabel from ${ }^{3} \mathrm{H}-\mathrm{TdR}$ was incorporated into DNA by marine plankton (Fig. 4). These findings support the arguments that ${ }^{3} \mathrm{H}$-Leu and ${ }^{3} \mathrm{H}$-TdR are specific for protein and DNA during short incubations (Kirchman et al. 1985, Moriarty 1986, Chin-Leo \& Kirchman 1988). Furthermore, enzymatic hydrolysis provided no evidence of temperaturedependent non-specific labelling of macromolecules (Fig. 4), indicating that temperature-dependent increases in Leu:TdR ratios were not a function of ${ }^{3} \mathrm{H}$-Leu and ${ }^{3} \mathrm{H}-\mathrm{TdR}$ incorporation into molecules other than protein and DNA, respectively.

The possibility that temperaturedependent Leu:TdR ratios in the present study were a function of substrate limitation also seems unlikely. Substrate saturation is an important consideration where LI, TTI, and Leu:TdR ratios all increase with temperature. Under such conditions, substrate limitation (specifically TdR limitation relative to Leu) could explain the increase in Leu:TdR ratios. However, substrate limitation is not a suitable explanation for successive increases in Leu:TdR ratios when there is psychrotrophic-

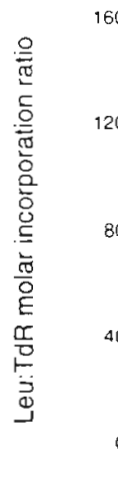

mesophilic growth, e.g. when TTI increases between 4 and $12^{\circ} \mathrm{C}$, and then decreases between 12 and $30^{\circ} \mathrm{C}$, as for Oudekraal bacterioplankton and 3 of the isolates. There was a temperature-dependent increase in Leu:TdR incorporation in all experiments, including those where there was psychrotrophic-mesophilic growth, indicating that $T d R$ concentration was not a factor of variation in Leu:TdR ratios. Furthermore, experiments with inshore and oceanic seawater showed that TTl was saturated at $5 \mathrm{nM}$ additions of
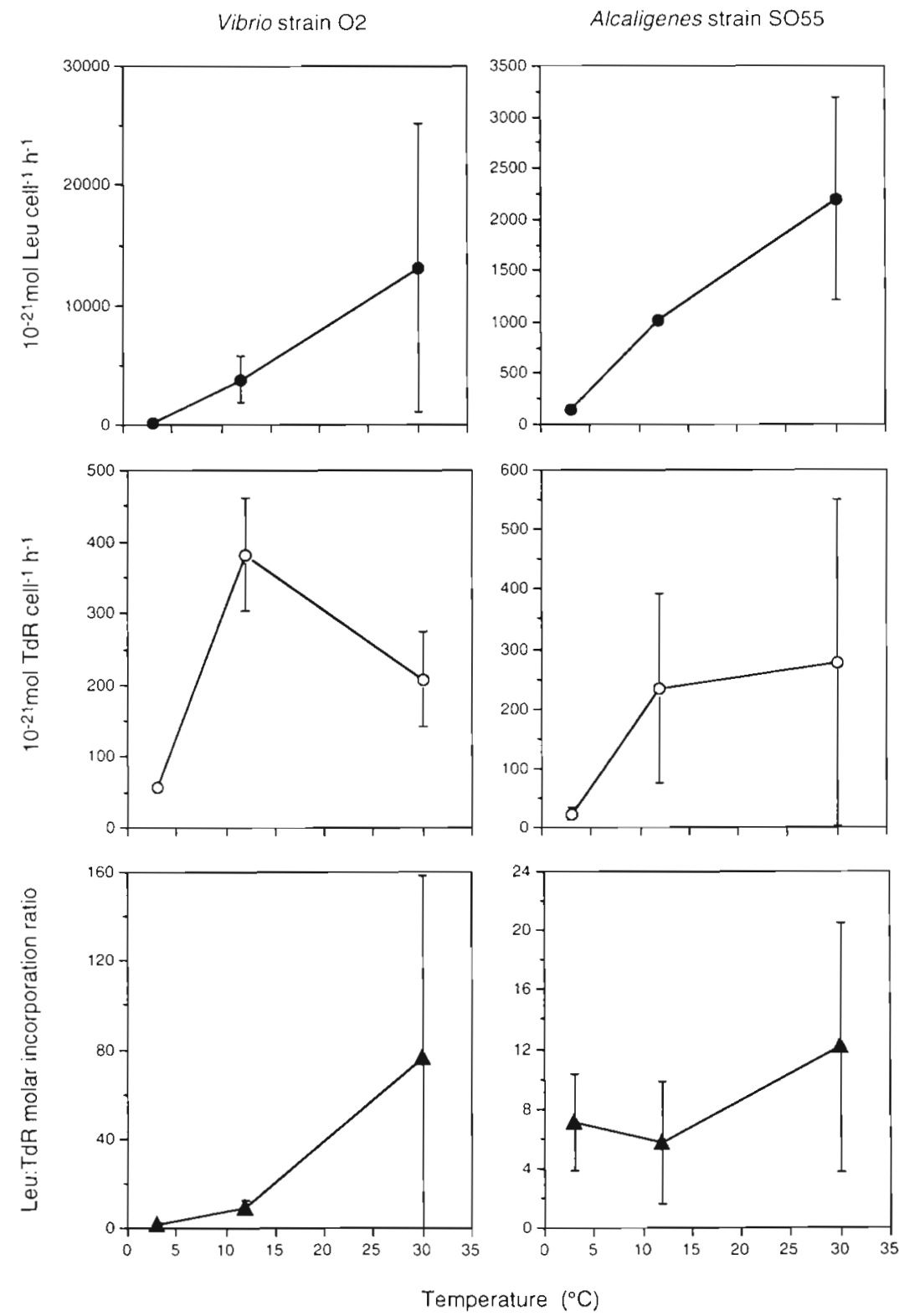

Fig. 7. Effect of temperature on LI, TTI, and the molar ratio of Leu:TdR incorporation by 2 marine bacterial isolates. Note that the scales for substrate incorporation differ between isolates. Two separate experiments using duplicate subsamples were conducted for each isolate. Values for LI, TTI, and Leu:TdR represent means \pm SD for duplicate experiments 
${ }^{3} \mathrm{H}-\mathrm{TdR}$ (Fig. 5), while an experiment with inshore bacterioplankton showed that Leu:TdR ratios also increased with temperature at higher substrate concentrations $([\mathrm{TdR}]$ at $5,10,30 \mathrm{nM}$, [Leu] at 10, 20, $60 \mathrm{nM}_{\text {; Fig. 6). }}$

The effects of temperature on rates of LI and TTI can also be compared by $Q_{10}$ values (Fig. 9). $Q_{10}$ values for LI were higher than corresponding $Q_{10}$ values for TTI for all studies except 3 values for the Alcaligenes strain SO55, which were marginally lower than the TTI val-
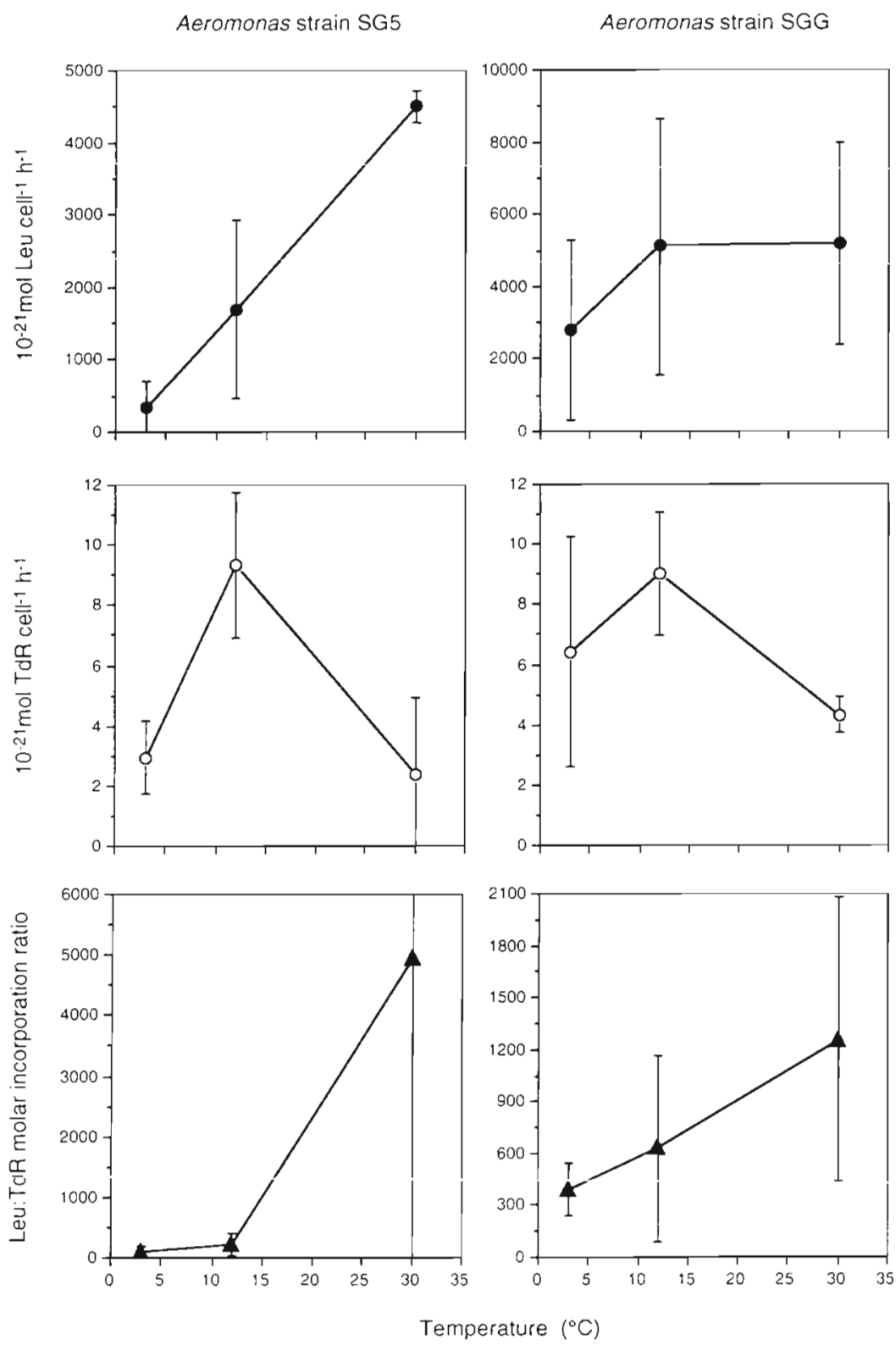

Fig. 8. Effect of temperature on LI, TTI, and the molar ratio of Leu:TdR incorporation by 2 bacterial isolates from a freshwater stream. Note that the scales for substrate incorporation may differ between isolates. Two separate experiments using duplicate subsamples were conducted for each isolate. Values for LI, TTI, and Leu:TdR represent means \pm SD for duplicate experiments ues. Statistical analysis by paired $t$-test indicated that differences in Leu and TdR $Q_{10}$ values were highly significant $(p=0.001)$. Thus, Leu incorporation increased more rapidly than $T d R$ incorporation when rates exhibited a positive response to an increase in temperature, and decreased more slowly than TdR incorporation when there was a negative response to an increase in temperature. More significantly, $Q_{10}$ values for Leu incorporation into protein were greater than corresponding $\mathrm{Q}_{10}$ values for $\mathrm{TdR}$ incorporation into DNA, as indicated by enzymatic hydrolysis (Fig. 9). This comparison refers to the basis of these methodologies, i.e. TTI and LI are based on rates of DNA and protein synthesis, respectively.

The effect of relatively higher LI $Q_{10}$ values on Leu:TdR ratios may have consequences for the methodology of bacterial production measurements, since they indicate that the ratio of the conversion factors (for Leu and $T d R$ ) is not constant with respect to temperature. Several authors have compared bacterial production estimated by TTI and LI for marine (Simon \& Azam 1989) and freshwater (Riemann \& Bell 1990) ecosystems, and have noted that the 2 methods gave similar estimates. Moreover, Servais (1992) compared TdRand Leu-derived estimates over a. range of aquatic ecosystems (from oligotrophic to eutrophic systems, and a range of 4 orders of magnitude in bacterial activity) and found a significant correlation between incorporation rates. However, none of these authors have reported that their work involved environments that differ considerably in temperature.

More recently, Shiah \& Ducklow (1994) examined the effects of temperature and substrate availability on estuarine bacterial production (measured by TTI and LI) and presented regressions for $\ln \left(\mathrm{TdR}\right.$ cell $\left.^{-1}\right)$ and

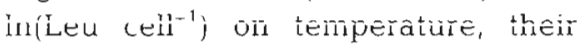
data are compared in Fig 10. Statistical analysis (by paired $t$-test) of their data shows that Leu regressions were significantly ( $\mathrm{p}<0.001)$ higher than TdR regressions (Fig. 10). Moreover, temperature-manipulation experiments with samples from Lake Constance also showed that molar Leu:TdR incorporation increased with temperature 


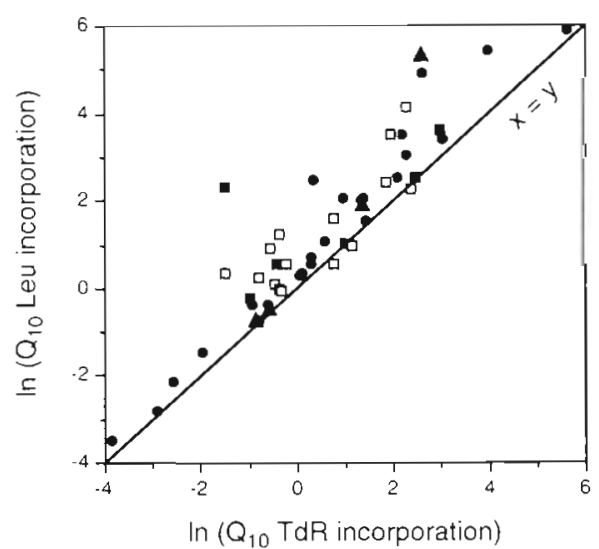

Fig. 9. Comparison of $Q_{10}$ values for Ll and TTI by bacterioplankton and bacterial isolates. ( LI and TTI into cold-TCA insoluble material; (4) LI and TTI into 'protein' and 'DNA' fractions determined by acid-base hydrolysis; (- Ll and TTI into protein and DNA determined by enzymatic hydrolysis; (ㅁ) LI and TTI into cold-TCA insoluble material by bacterial isolates

(M. Simon pers. comm.). These observations support the present hypothesis that variations in Leu:TdR ratios are a function of temperature. Thus, conversion factors for LI and TTI should be determined for thermally different environments. The results of the present study might have particular relevance for environments where considerable thermal diversity is encountered (e.g. the Southern Ocean), but may also be of importance to larger-scale scientific programmes (e.g. the Joint Global Ocean Flux Study), which aim to model the global dynamics of planktonic processes with high resolution based on data collected from multiple sources.

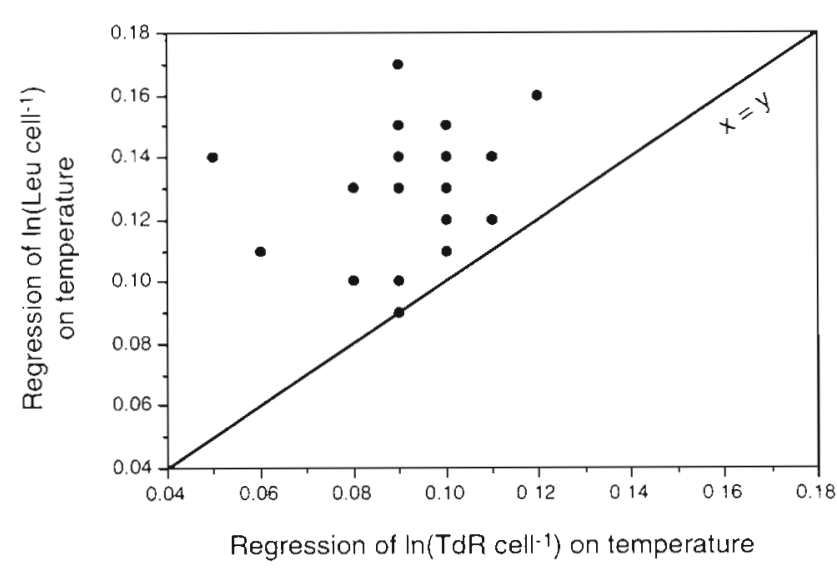

Fig. 10. Comparison of the effect of temperature of LI with its effect on TTI by bacteria in Chesapeake Bay, USA. Data represent slopes for the linear regression of natural-log-transformed cell-specific rates of TTI and Ll on temperature. Data from Shiah \& Ducklow (1994)
Acknowledgements. I thank John Field, Richard Robarts, Meinhard Simon and 2 anonymous referees for constructive criticisms of an earlier version of this manuscript. This study was supported by funds from the South African Department of Environmental Affairs and Toursm, and an FRD Core Grant to G. M. Branch, J. G. Field, and C. L. Gruffiths.

\section{LITERATURE CITED}

Azam F, Fenchel T, Field JG, Gray JS, Meyer-Reil LA, Thingstad F (1983) The ecological role of water-column microbes in the sea. Mar Ecol Prog Ser 10:257-263

Bell RT (1990) An explanation for the variability in the conversion factor deriving bacterial cell production from incorporation of $\left[{ }^{3} \mathrm{H}\right]$ thymidine. Limno] Oceanogr 35 : 910-915

Bjornsen PK, Kuparinen J (1991) Determination of bacterioplankton biomass, net production and growth efficiency in the Southern Ocean. Mar Ecol Prog Ser 71:185-194

Chin-Leo G, Kirchman DL (1988) Estimating bacterial production in marine waters from the simultaneous incorporation of thymidine and leucine. Appl Environ Microbiol $54: 1934-1939$

Chin-Leo G, Kirchman DL (1990) Unbalanced growth in natural assemblages of marine bacterioplankton. Mar Ecol Prog Ser 63:1-8

Cho BC. Azam F (1988) Major role of bacteria in biogeochemical fluxes in the ocean's interior. Nature 332:441-443

Cole JJ, Findlay S, Pace ML (1988) Bacterial production in fresh and saltwater ecosystems: a cross-system overview. Mar Ecol Prog Ser 43:1-10

Davis CL (1989) Uptake and incorporation of thymidine by bacterial isolates from an upwelling environment. Appl Environ Microbiol 55:1267-1272

Ducklow HW, Carlson CA (1992) Oceanic bactenal production. Adv Microb Ecol 12:113-181

Froneman PW, MCQuaid CD, Perissinotto R (1995) Biogeographic structure of the microphytoplankton assemblages of the south Atlantic and Southern Ocean during austral summer. J Plankton Res 17:1791-1802

Fuhrman JA, Azam F (1982) Thymidine incorporatıon as a measure of heterotrophic bacterioplankton production in marine surface waters: evaluation and field results. Mar Biol 66:109-120

Fuhrman JA, Sleeter TD, Carlson CA, Proctor LM (1989) Dominance of bacterial biomass in the Sargasso Sea and its ecological implications. Mar Ecol Prog Ser 57 : $207-217$

Hollibaugh JT (1988) Limitations of the $\left[^{3} H\right]$ thymidine method for estimating bacterial productivity due to thymidine metabolism. Mar Ecol Prog Ser 43:19-30

Karl DM (1982) Selected nucleic acid precursors in studies of aquatic microbial ecology. Appl Environ Microbiol 44: $891-902$

Kirchman D, K'nees E, Hodson R (1985) Leucine incorporation and its potential as a measure of protein synthesis by bacteria in natural aquatic systems. Appl Environ Microbiol 49:599-607

Kirchman DL (1992) Incorporation of thymidine and leucine in the subarctic Pacific: application to estimating bacterial production. Mar Ecol Prog Ser 82:301-309

Kirchman DL, Hoch MP (1988) Bacterial production in the Delaware Bay estuary estimated from thymidine and leucine incorporation rates. Mar Ecol Prog Ser 45:169-178

Lutjeharms JRE, Valentine HR (1984) Southern Ocean thermal fronts south of Africa. Deep Sea Res 31:1461-1475 
Lutjeharms JRE, Valentine HR (1.987) Water types and volumetric considerations of the south-east Atlantic upwelling regime. S Afr J Mar Sci 5:63-71

Monarty DJW (1986) Measurement of bacterial growth rates in aquatic systems from rates of nucleic acid synthesis Adv Microb Ecol 9:245-292

Moriarty DJW (1988) Accurate conversion factors for calculating growth rates from thymidine incorporation into DNA: elusive or illusive? Arch Hydrobiol Beih Ergebn Limnol 31:211-217

Porter KG, Feig YS (1980) The use of DAPI for identifying and counting aquatic microflora. Limnol Oceanogr 25: $943-948$

Riemann B, Bell RT (1990) Advances in estimating bacterial biomass and growth in aquatic systems. Arch Hydrobiol 118:385-402

Robarts RD, Wicks RJ (1989) |Methyl- ${ }^{3} \mathrm{H}$ |thymidine macromolecular incorporation and lipid labeling: their significance to DNA labeling during measurements of aquatic bacterial growth rate. Limnol Oceanogr 34:213-222

Robarts RD, Wicks RJ, Sephton LM (1986) Spatial and temporal variations in bacterial macromolecule labeling with [methyl- ${ }^{3} \mathrm{H}$ ] thymidine in a hypertrophic lake. Appl Environ Microbiol 52:1368-1373

Robarts RD, Zohary T (1993) Fact or fiction - bacterial growth rates and production as determined by $\left[\right.$ methyl- $\left.{ }^{3} \mathrm{H}\right]$-thymidine? Adv Microb Ecol 13:371-425

Sambrook J, Fritsch EF, Maniatis T (1989) Molecular cloning a laboratory manual. Cold Spring Harbor Laboratory Press, New York

Servais $P$ (1992) Bacterial production measured by ${ }^{3} \mathrm{H}$-thymidine and ${ }^{3} \mathrm{H}$-leucine incorporation in various aquatic ecosystems. Arch Hydrobiol Beih Ergebn Limnol 37: $73-81$

Servais P, Martinez J, Billen G, Vives-Rego J (1987) Determining $\left[{ }^{3} \mathrm{H}\right]$ thymidine incorporation into bacterioplankton

Responsible Subject Editor: F. Azam, La Jolla, Californid, USA
DNA: improvement of the method by DNase treatment. Appl Environ Microbiol 53:1977-1979

Shannon LV (1985) The Benguela Ecosystem Part I. Evolution of the Benquela, physical features and processes. Oceanogr Mar Biol Ann Rev 23:105-182

Shannon LV, Stander GH (1977) Physical and chemical characteristics of water in Saldanha Bay and Langebaan Lagoon. Trans R Soc S Afr 42:441-459

Shiah FK, Ducklow HW (1994) Temperature and substrate regulation of bacterial abundance, production and specific growth rate in Chesapeake Bay, USA. Mar Ecol Prog Ser 103:297-308

Simon M (1994) Diel variability of bacterioplankton biomass production and cell multiplication in Lake Constance Arch Hydrobiol 130:283-302

Simon M, Azam F (1989) Protein content and protein synthesis rates of planktonic marine bacteria. Mar Ecol Prog Ser 51:201-213

Simon M, Cho BC, Azam F (1992) Significance of bacterial biomass in lakes and the ocean: comparison to phytoplankton biomass and biogeochemical implications. Mar Ecol Prog Ser 86:103-110

Smibcrt RM, Krieg NR (1981) General characterization. In Gerhardt et al. (eds) Manual of methods for general bacteriology. ASM, Washington, DC, p 409-443

Tibbles BJ, Davis CL, Harris JM, Lucas MI (1992) Estimates of bacterial productivity in marine sediments and water from a temperate saltmarsh lagoon. Microb Ecol 23:195-209

Tibbles BJ, Harris JM (1996) Use of radiolabelled thymidine and leucine to estimate bacterial production in soils from continental Antarctica. Appl Environ Microbiol 62: $694-701$

Torreton JP, Bouvy M (1991) Estimating bacterial DNA synthesis from $\left[{ }^{3} \mathrm{H}\right]$ thymidine incorporation: discrepancies among macromolecular extraction procedures. Limnol Oceanogr 36:299-306

Manuscript first received: March 22, 1996

Revised version accepted: August 19, 1996 